\title{
Analisis Pembangkit Listrik Sistem Hybrid Grid Connected Di Villa Peruna Saba, Gianyar - Bali
}

\author{
Gordon Arifin Sinaga ${ }^{1}$, I Made Mataram ${ }^{2}$, Tjok Gede Indra Partha ${ }^{3}$ \\ 1,2,3 Program Studi Teknik Elektro, Fakultas Teknik, Universitas Udayana \\ Email : gordonsinaga96@gmail.com,mataram@unud.ac.id, cokindra@ee.unud.ac.id
}

\begin{abstract}
Abstrak
Energi terbarukan merupakan energi yang berasal dari proses alam yang tidak akan pernah habis dan berkelanjutan jika dikelola dengan baik. Diantara berbagai sumber energi terbarukan yang tersedia, energi matahari mempunyai potensi yang besar untuk dimanfaatkan sebagai salah satu sumber energi listrik pada daerah tropis. Dalam pemanfaatannya, untuk menjaga keberlanjutan ketersediaan energi listrik secara maksimal maka diperlukan penggabungan beberapa jenis pembangkit yang terhubung dengan jaringan listrik PLN atau yang lebih dikenal dengan sebutan pembangkit listrik sistem hybrid grid connected. Penelitian ini bertempat di Villa Peruna Saba, Gianyar - Bali yang menggunakan pembangkit listrik sistem hybrid grid connected. Sistem ini menggabungkan antara photovoltaic dan genset yang terhubung dengan jaringan PLN dalam menyuplai beban listrik. Analisis dilakukan terhadap karakteristik beban rata - rata, kontribusi masing - masing sumber daya listrik dan cara kerja pembangkit listrik sistem hybrid grid connected. Hasil penelitian ini menunjukkan bahwa kontribusi daya yang berasal dari pembangkit listrik tenaga surya adalah sebesar 561,27 kW atau 22,41\% pada bulan April 2018 dan 510,72 kW atau 20,71\% pada bulan Mei 2018.
\end{abstract}

Kata Kunci : Energi Terbarukan, Fotovoltaik, Sistem Hibrida, .

\begin{abstract}
Renewable energy is energy that comes from natural processes that will not be exhausted and sustainable if managed properly. In its use, to maintain the continuity of the availability of electrical energy maximally, it is necessary to combine several types of power plants that are connected to the grid or better known as hybrid grid connected power systems. This research took place at Villa Peruna Saba, Gianyar - Bali which uses a hybrid grid connected power system that combines photovoltaics and generators connected to the grid utilty in supplying electricity loads. The analysis is carried out on the characteristics of the average load, the contribution of each electric power source and the workings of the hybrid grid connected hybrid power plant system. From the analysis, it is known that the contribution of power derived from solar power plants is $561.27 \mathrm{~kW}$ or $22.41 \%$ in April 2018 and $510.72 \mathrm{~kW}$ or $20.71 \%$ in May 2018.
\end{abstract}

Keywords : Renewable Energy, Photovoltaic, Hybrid System.

\section{PENDAHULUAN}

Energi listrik merupakan energi yang sangat penting dalam menunjang aktivitas manusia, sekaligus sebagai kebutuhan mutlak untuk menunjang pembangunan nasional yang berkelanjutan [1]. Hal ini menjadi tantangan besar bagi Indonesia ketika dihadapkan pada kondisi dimana sebagian besar penyediaannya masih bergantung pada energi fosil. Energi fosil menghasilkan polusi yang merusak dan berbahaya terhadap lingkungan. Energi terbarukan dibutuhkan untuk menunjang kebutuhan energi listrik yang semakin hari semakin meningkat. Selain itu energi terbarukan lebih ramah lingkungan dan tidak menimbulkan polusi seperti yang ditimbulkan oleh energi fosil lainnya. Oleh karena itu, sudah saatnya indonesia beralih menggunakan energi terbarukan yang lebih ramah lingkungan. Di Indonesia, energi matahari mempunyai potensi yang besar 
untuk dimanfaatkan sebagai salah satu sumber energi terbarukan [2]. Pemanfaatan energi matahari menjadi energi listrik disebut sebagai pembangkit listrik tenaga surya. Energi listrik yang dihasilkan oleh pembangkit listrik tenaga surya tersebut sangat dipengaruhi oleh intensitas radiasi cahaya matahari yang diterima oleh sistem sehingga daya listrik yang dihasilkan berfluktuasi. Beberapa kasus banyak yang menggabungkan pembangkit listrik tenaga surya dan pembangkit listrik tenaga diesel. Agar pemanfaatannya lebih optimal maka pembangkit listrik sistem hybrid dihubungkan dengan jaringan listrik PLN [3]. Dengan adanya pembangkit listrik sistem hybrid diharapkan dapat mengurangi biaya yang dibayarkan terhadap daya yang berasal dari PLN.

Villa Peruna menggunakan pembangkit hybrid untuk memenuhi kebutuhan energi listriknya yaitu dengan menggabungkan pembangkit listrik tenaga surya (PLTS) dan pembangkit listrik tenaga diesel (Generator Set) yang terhubung langsung dengan jaringan PLN atau biasa disebut (hybrid sytem grid connected.).

Penelitian ini menganalisis Pembangkit Listrik Sistem Hybrid Grid Connected yang terdapat di Villa Peruna Saba, Gianyar Bali. Dengan dilakukannya penelitian ini diharapkan nantinya dapat memberikan gambaran dan masukan tentang pemanfaatan pembangkit listrik sistem hybrid grid connected serta mengetahui proses yang terjadi disaat pembangkit tersebut beroperasi.

\section{KAJIAN PUSTAKA \\ 2.1 Defenisi Energi}

Energi adalah kemampuan untuk melakukan kerja yang dapat berupa panas, cahaya, mekanika, kimia dan elektromagnetik. Energi merupakan sesuatu yang bersifat abstrak yang sukar dibuktikan tetapi dapat dirasakan keberadaanya. Energi bersifat fleksibel artinya dapat berpindah dan berubah. Sehingga dapat disimpulkan bahwa energi merupakan sebagai daya atau kekuatan yang diperlukan untuk melakukan berbagai proses kegiatan [4].

Energi terbarukan adalah sumber energi yang dihasilkan dari sumber daya energi yang secara alamiah tidak akan habis dan dapat berkelanjutan jika dikelola dengan baik, antara lain : panas bumi, biofuel, aliran air sungai, panas surya, angin, biomassa, biogas, ombak laut, dan suhu kedalaman laut. [5].

\subsection{Pembangkit Listrik Tenaga Surya}

Photovoltaic atau Pembangkit listrik tenaga surya adalah pembangkit listrik yang mengubah energi surya menjadi energi listrik. Kata photovoltaic berasal dari Bahasa Yunani yaitu "photo" berarti cahaya dan "voltaic" berarti tegangan [6]. Pada prinsipnya pemanfaatan energi surya sebagai tenaga pembangkit energi listrik bertumpu pada sebuah elemen fotolistrik yang berfungsi sebagai pengubah energi cahaya menjadi energi listrik yang biasa disebut sel surya atau solar cell [7]. Karena sebuah sel surya hanya menghasilkan tegangan dan arus listrik yang sangat kecil maka beberapa sel surya dirangkai sedemikian rupa sehingga menjadi sebuah panel surya atau solar panel. Energi listrik yang dihasilkan oleh panel surya berupa listrik arus searah (direct current) tegangan rendah. Energi listrik ini nantinya akan dikumpulkan dan disimpan dalam sebuah akumulator (aki/accu) lewat sebuah alat kontrol pengisian aki atau biasa disebut solar charge controller.

\subsection{Daya dan Efisiensi Sel Surya.}

Efisiensi yang terdapat pada sel surya merupakan perbandingan daya listrik yang dapat dibangkitkan oleh sel surya dengan energi input yang diperoleh dari sinar matahari. Efisiensi konversi energi ( $\eta$ ) adalah rasio antara output yang berguna mesin konversi energi dan input, dalam hal energi. Output yang berguna mungkin tenaga listrik, kerja mekanik, atau panas .

Daya yang dapat diperoleh dari konversi sinar matahari secara umum dirumuskan sebagai berikut [8] :

$$
\mathrm{P}_{\text {input }}=\mathrm{I} \times \mathrm{A} \text { (Watt) }
$$

Dengan :

$$
\begin{gathered}
\mathrm{I}=\underset{\left(\mathrm{w} / \mathrm{m}^{2}\right)}{\text { Intensitas radiasi matahari }} \\
\mathrm{A}=\underset{\left(\mathrm{m}_{2}\right)}{\operatorname{Luas}} \text { permukaan } \mathrm{PV} \text { Module }
\end{gathered}
$$

Efisiensi yang terdapat pada sel surya dapat ditentukan dengan rumus :

$$
\begin{array}{ll}
\eta & =\frac{\text { Poutput }}{\text { I.A }} \\
\eta & =\frac{\text { Poutput }}{\text { Pinput }}
\end{array}
$$

Dengan :

$\mathrm{P}_{\text {output }}=$ Daya output dari sel surya (w att)

$\mathrm{P}_{\text {input }}=$ Daya input dari sel surya (watt)

$\mathrm{I}=$ Intensitas radiasi matahari $(\mathrm{w} / \mathrm{m})$ 
A = Luas permukaan sel surya $\left(\mathrm{m}^{2}\right)$

Daya output dari sel surya dapat ditentukan dengan rumus :

$\mathrm{P}_{\text {out }}=\mathrm{I} \times \mathrm{A} \times \eta$ (watt)

Dengan :

$$
\begin{aligned}
& \mathrm{I}=\text { Intensitas radiasi matahari } \\
& \left(\mathrm{w} / \mathrm{m}^{2}\right) \\
& \mathrm{A}=\text { Luas permukaan PV Module }\left(\mathrm{m}^{2}\right) \\
& \eta=\text { Efisiensi sel surya }(\%)
\end{aligned}
$$

\section{METODOLOGI PENELITIAN}

Penelitian ini dilakukan di Villa Peruna Saba, Gianyar - Bali. Waktu pelaksanaan penelitian dimulai pada bulan April 2018 sampai dengan Mei 2018. Sumber data dalam pembahasan diperoleh dari Villa Peruna Saba, Gianyar - Bali dan BMKG Stasiun Meteorologi Klas I Ngurah Rai. Teknik pengumpulan data yang digunakan adalah berdasarkan observasi dan studi literatur.

Adapun langkah - langkah dalam penelitian ini dilakukan dalam beberapa tahapan sebagai berikut:

1. Pengumpulan data primer maupun data sekunder seperti spesifikasi peralatan dan parameter daya listrik dari masing masing sumber dan beban.

2. Melakukan pengolahan data dan analisis terhadap data primer dan data sekunder yang telah didapat. Data Beban, Daya Output PLTS dan Daya PLN diperoleh selama 24 jam dalam waktu dua bulan kemudian dicari rata rata.

3. Membuat kesimpulan dari hasil analisis yang telah dilakukan.

\section{HASIL DAN PEMBAHASAN}

\subsection{Sistem Kelistrikan di Villa Peruna} Saba, Gianyar - Bali.

Sistem yang menyuplai listrik di Villa Peruna Saba, Gianyar - Bali adalah pembangkit listrik sistem hybrid yang terhubung dengan jaringan utiitas (Grid Connected). Sistem tersebut terdiri dari beberapa sumber yaitu Pembangkit Listrik Tenaga Surya, Pembangkit Listrik Tenaga Diesel (Genset), Battery bank dan Jaringan Utilitas (PLN).

Komponen - komponen dari sistem hybrid tersebut sebagai berikut:

1. Daya listrik yang terpasang dari PLN yang terpasang sebesar 23 KVA.

2. Pembangkit Listrik Tenaga Surya yang terpasang dengan kapasitas 3,5 kW.

3. Pembangkit Listrik Tenaga Diesel (Genset) dengan kapasitas 28 kW.
4. Inverter Bi-directional dan Controller (SP PRO Selectronic).

5. Grid Tie Inverter (KACO Powador)

6. Battery bank dengan kapasitas 38,4 kWAh

Gambar 1 memperlihatkan sistem kelistrikan di Villa Peruna Saba, Gianyar Bali.

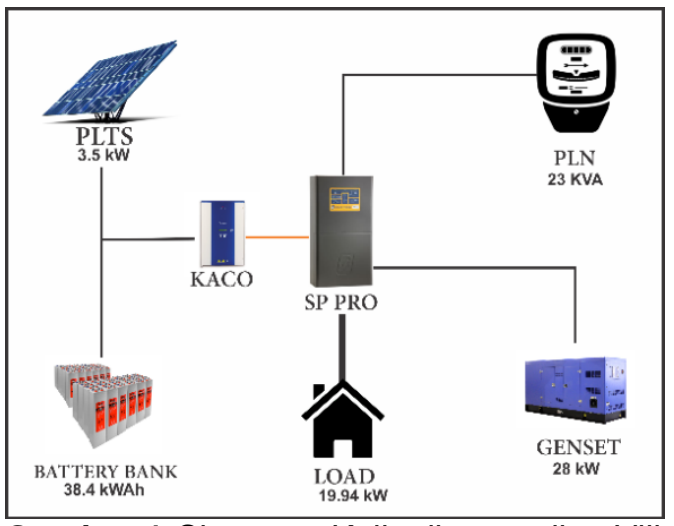

Gambar 1 Sistem Kelistrikan di Villa Peruna Saba, Gianyar - Bali.

Pembangkit listrik sistem hybrid yang menyuplai listrik di Villa Peruna Saba, Gianyar - Bali merupakan sistem hybrid yang terhubung dengan jaringan listrik PLN (Grid Connected). Pembangkit listrik sistem hybrid bekerja secara terintegrasi untuk menyuplai beban di Villa Peruna Saba, Gianyar - Bali. Terdapat 4 jenis sumber yang menyuplai beban di Villa diantaranya : Jaringan Utilitas (PLN), Battery Bank, Solar Panel dan Generator Diesel (Genset). Semua sumber tersebut bekerja secara terintegrasi dan dikontrol oleh sebuah inverter controller. Inverter controller yang digunakan adalah SP PRO Series. SP PRO Series merupakan komponen dari sistem hybrid yang berfungsi sebagai inverter dan juga controller. SP PRO Series mempunyai sifat yang bi-directional yaitu mampu mengubah listrik $A C$ ke $D C$ dan $D C$ ke $A C$. SP PRO Series merupakan pusat dari semua sistem hybrid dalam beroperasi guna memenuhi kebutuhan energi listrik di Villa Peruna Saba, Gianyar - Bali. SP PRO Series juga berkomunikasi dengan inverter Grid Tie KACO Powador dalam penyuplaian listrik ke beban. Inverter Grid Tie KACO Powador bisa menyuplai daya listrik dari PLTS ke SP PRO Series dan juga menyuplai daya listrik dari PLTS untuk melakukan charging ke battery bank melalui SP PRO Series.

Proses penyuplaian energi listrik oleh pembangkit listrik sistem hybrid tergantung 
pada fluktuasi beban yang terdapat di Villa Peruna. Pada saat sel surya menyuplai daya, KACO Powador akan menyinkronkan frekuensi dan tegangan dari jaringan (PLN) sehingga frekuensi dan tegangan antara KACO Powador akan sama dengan frekuensi dan tegangan dari PLN dalam menyuplai beban. Tetapi jika PLN padam, maka KACO Powador akan menyesuaikan frekuensi dan tegangan dari SP PRO Series sehingga bisa tetap menyuplai beban. Proses penyesuaian frekuensi dan tegangan tersebut memiliki ada jeda waktu sampai dapat kembali beroperasi normal.

Proses penyuplaian beban terbagi menjadi 2 waktu yaitu pada saat siang hari (saat PLTS beroperasi) dan pada saat malam hari (saat PLTS tidak beroperasi). Pada siang hari saat cahaya matahari tersedia, suplai daya listrik utama akan diambil dari pembangkit listrik tenaga surya kemudian PLN dan juga battery bank. Jika PLN off, maka beban listrik di villa akan disuplai oleh PLTS dan Battery Bank. Jika PLTS off maka PLN akan beban akan disuplai PLN dan Battery Bank. Pada saat malam hari suplai daya listrik utama diambil dari PLN kemudian Battery bank. Pembangkit Listrik Tenaga Diesel (Generator Set) hanya akan beroperasi ketika suplai dari PLN padam, Battery Bank dan Pembangkit Listrik Tenaga Surya tidak mampu untuk menyuplai beban listrik di Villa Peruna Saba, Gianyar - Bali.

\subsection{Karakteristik Beban di Villa Peruna Saba, Gianyar - Bali}

Karakteristik beban di Villa Peruna Saba, Gianyar - Bali dapat diketahui dengan melakukan penelitian selama 2 bulan yaitu pada bulan April sampai dengan Mei 2018.

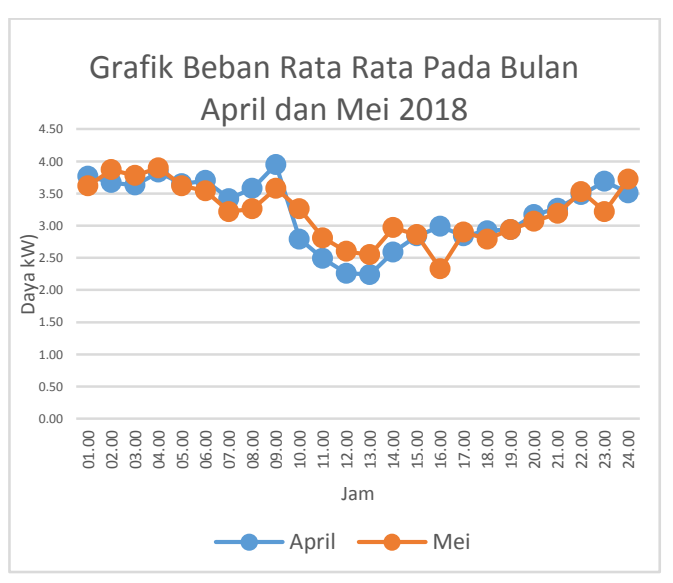

Gambar 2 Karakterstik Beban di Villa Peruna Saba, Gianyar - Bali.

Gambar 2 dapat meperlihatkan bahwa perubahan beban dari pagi sampai malam tidak terlalu besar. Pada gambar 2 dapat dilihat bahwa beban puncak terjadi pada jam 09.00 untuk bulan April yaitu sebesar $3,95 \mathrm{~kW}$ dan jam 04.00 untuk bulan Mei yaitu sebesar 3,90 kW. Salah satu faktor yang menentukan besar kecilnya beban listrik di sebuah rumah adalah peralatan listrik yang terdapat pada Villa tersebut. Hal ini menyebabkan fluktuasi beban di Villa Peruna Saba, Gianyar - Bali tidak terlalu signifikan.

\subsection{Daya Output Pembangkit Listrik Tenaga Surya}

Data daya output PLTS diperoleh dari software SP Link yang melakukan pembacaan pada secara otomatis data tentang pembangkitan listrik pembangkit listrik tenaga surya.

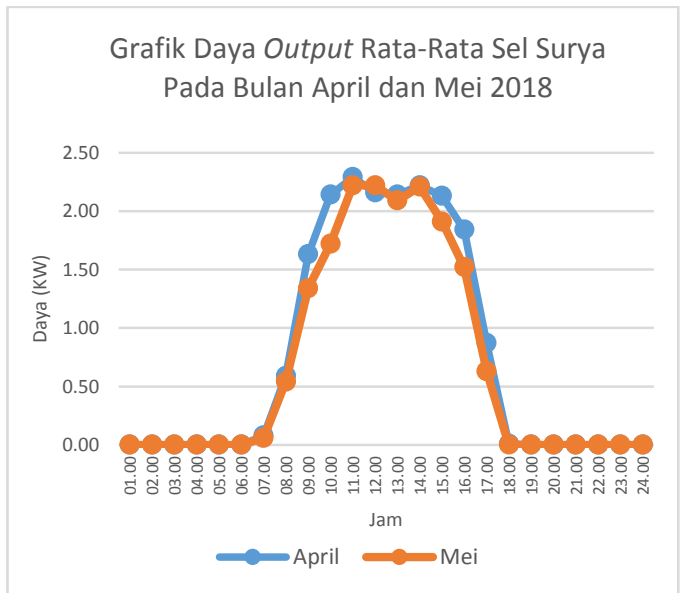

Gambar 3 Gafik Daya Output Rata - Rata Sel Surya

Gambar 3 menunjukkan bahwa jam operasional dari pembangkit listrik tenaga surya dimulai dari jam 07.00 sampai dengan jam 17.00. PLTS mulai menghasilkan daya listrik pada jam 07.00 yaitu sebesar 0,06 kW, kemudian pada jam 07.00 sampai dengan jam 11.00 grafik output daya mengalami kenaikan yang cukup signifikan. Hal ini dikarenakan cahaya matahari sudah mulai terbit hingga pada siang hari jam 11.00 sehingga otomatis intensitas radiasi matahari juga ikut mengalami peningkatan. Kemudian pada jam 12.00 sampai jam 13.00 grafik daya listrik mengalami penurunan, setelah itu pada jam 14.00 grafik daya listrik mengalami peningkatan. Pada jam 15.00 
sampai dengan jam 17.00 grafik daya output listrik mengalami penurunan yang cukup signifikan.

Daya output pembangkit listrik tenaga surya yang didapatkan secara real melalui pengukuran tidak pernah mencapai daya maksimal yang tercatat di pada spesifikasi. Hal ini dikarenakan oleh beberapa faktor yaitu intensitas radiasi matahari, tata letak dari sel surya, efek shading dan juga usia dari panel surya tersebut. Hal lain yang mempengaruhi besar daya output dari sel surya diatas adalah tata letak sel surya tersebut. Panel surya pada Villa Peruna Saba, Gianyar - Bali diletakkan dengan menghadap ke arah barat daya. Sehingga hal ini menyebabkan efektivitas penyinaran sel surya lebih kecil dibanding jika sel surya diletakkan dengan menghadap ke arah utara. Faktor lainnya adalah efek shading, efek shading merupakan kemungkinan terhalangnya panel surya akibat dari bayangan suatu benda sehingga mengakibatkan berkurangnya radiasi sinar matahari yang dapat diterima oleh sel sel pada panel surya. Dalam hal ini efek shading disebabkan oleh adanya pohon pinang yang menghalangi datangnya radiasi matahari dari sebelah utara. Usia dari penggunaan peralatan dalam hal ini usia panel surya juga sangat mempengaruhi performance dari panel surya itu sendiri. Semakin lama usia penggunaan suatu peralatan maka semakin menurun juga efisiensinya, pada kasus panel surya di Villa Peruna Saba, Gianyar Bali panel surya tersebut sudah 5 tahun beroperasi. Sehingga hal ini menyebabkan berkurangnya tingkat efisiensi dari panel surya itu sendiri.

\subsection{Pasokan Energi Listrik dari PLN}

Daya terpasang pada Villa Peruna Saba, Gianyar - Bali berasal dari PLN adalah sebesar $23 \mathrm{KVA}$, KWH Meter yang terpasang merupakan tipe $\mathrm{KWH}$ Meter pasca bayar. Daya listrik rata - rata yang disuplai dari PLN pada bulan April dan Mei 2018 dapat dilihat pada gambar 4.

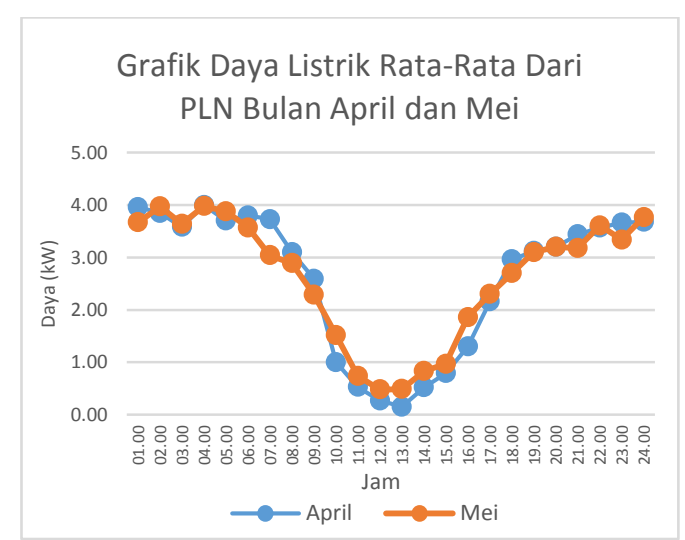

Gambar 4 Grafik Daya Listrik Rata - Rata dari PLN

Daya listrik yang terpasang dari PLN mengalami perubahan yang cukup signifikan seperti yang ditunjukkan pada gambar 4. Gambar 4 menunjukkan bahwa terjadi penurunan daya listrik PLN pada jam 07.00 sampai dengan jam 13.00. Hal ini disebabkan karena pada rentang waktu tersebut PLTS beroperasi untuk menyuplai beban di Villa Peruna Saba, Gianyar - Bali, sehingga daya dari PLN dikurangi pasokannya. Kemudian pada jam 14.00 sampai dengan jam 23.00 grafik daya listrik dari PLN mulai naik. Hal ini dikarenakan cahaya matahari sudah mulai terbenam ke arah barat, sehingga daya output dari pembangkit listrik tenaga surya semakin kecil. Daya listrik dari PLN pun digunakan untuk menyuplai beban listrik di Villa Peruna Saba, Gianyar - Bali.

\subsection{Penghematan Dari Pembangkit Listrik Tenaga Surya Terhadap PLN.}

Besar daya listrik yang bisa dihemat pada pembangkit listrik sistem hybrid dapat dihitung berdasarkan kontribusi daya listrik yang dibangkitkan oleh pembangkit listrik tenaga surya. Kontribusi daya listrik yang dihasilkan oleh masing - masing sumber daya listrik bisa dilihat pada tabel 1 .

Tabel 1 Daya Listrik Yang Disuplai Masing - Masing Sumber

\begin{tabular}{|l|l|l|l|l|}
\hline $\begin{array}{l}\text { Bulan } \\
\text { Sumber }\end{array}$ & $\begin{array}{l}\text { PLTS } \\
(\mathrm{kW})\end{array}$ & $\begin{array}{l}\text { PLN } \\
(\mathrm{kW})\end{array}$ & $\begin{array}{l}\text { Battery } \\
\text { Bank } \\
(\mathrm{kW})\end{array}$ & $\begin{array}{l}\text { Beban } \\
(\mathrm{kW})\end{array}$ \\
\hline April & 561,27 & 1942,6 & 110,14 & 2393,73 \\
\hline Mei & 510,72 & 1954,3 & 43,2 & 2421,9 \\
\hline
\end{tabular}

Tabel 1 menunjukkan besar kontribusi daya masing - masing sumber dalam 
menyuplai beban listrik di Villa Peruna Saba, Gianyar - Bali. Daya listrik pada battery bank merupakan daya input (charging) yang berasal dari PLTS dan PLN, sehingga daya pada battery bank termasuk sebagai beban. Pada bulan April 2018 didapatkan persentase kontribusi PLTS sebesar 22,41\% dan persentase kontribusi PLN sebesar 77,58\%. Sedangkan pada bulan Mei 2018 didapatkan persentase kontribusi PLTS sebesar $20.71 \%$ dan persentase kontribusi PLN sebesar $79.29 \%$.

\section{KESIMPULAN}

Kesimpulan dari hasil penelitian ini adalah besar persentase kontribusi daya yang berasal dari PLTS sebesar 22,41\% dan persentase kontribusi daya PLN sebesar $77,58 \%$. Sedangkan pada bulan Mei 2018 didapatkan persentase kontribusi daya PLTS sebesar $20.71 \%$ dan persentase kontribusi daya PLN sebesar $79.29 \%$.

\section{DAFTAR PUSTAKA}

[1] Agung. Energi Listrik dan Manfaatnya dalam Kehidupan. Jakarta : Bumi Aksara. 2015.

[2] Dharma, A. Matahari Sebagai Energi Terbarukan. Jakarta: Aneka Ilmu. 2005.

[3] Bien, L.K. Wibowo, W. Perancangan Sistem Hibrid Pembangkit Listrik Tenaga Surya Dengan Jala Jala Listrik PLN Untuk Rumah Perkotaan. Jurnal Elektro Trisakti. 2008; VIII (1). 37-56.

[4] Astu P, Djati N. Mesin Konversi Energi. Yogyakarta : Andi Yogyakarta. 2006.

[5] Kemenkumham. Undang-Undang Republik Indonesia No.30 Tahun 2007 Tentang Energi. Jakarta. 2007.

[6] William K. Renewable Energy Handbook. Kanada : Aztext Press. 2009.

[7] Kristiati M. Sumber Energi Penghasil Listrik. Yogyakarta: Citra Aji Parama. 2011.

[8] Supranto. Teknologi Tenaga Surya. Yogyakarta : Global Pustaka Utama. 2015. 